\title{
Pharmacogenetic Study on the Effect of Rivastigmine on PS2 and APOE Genes in Iranian Alzheimer Patients
}

\author{
M. Zamani ${ }^{a, b} \quad$ M. Mehri ${ }^{a} \quad$ A. Kollaee ${ }^{a, b} \quad$ P. Yenki ${ }^{a}$ \\ M. Ghaffarpor ${ }^{a}$ M.H. Harirchian ${ }^{a} \quad$ M. Shahbazi ${ }^{c}$
}

${ }^{a}$ Department of Neurogenetics, Iranian Center of Neurological Research, and ${ }^{b}$ Department of Medical Genetics, School of Medicine, Tehran University of Medical Sciences, Tehran, and 'Medical Cellular and Molecular Research Center, Golestan University of Medical Sciences, Gorgan, Iran

\section{Key Words}

Alzheimer genetics • Alzheimer therapy $\cdot$ APOE4 $•$ Apolipoproteins $\cdot$ Genetic association • Presenilin • PS2

\begin{abstract}
Background/Aims: Alzheimer disease (AD) is a complex and genetically heterogeneous disorder, and certain genes such as PS2 and APOE4 contribute to the development of AD. Due to its heterogeneity, AD-predisposing genes could vary in different populations. Moreover, not all AD patients will respond to the same therapy. We specifically investigated the effect of rivastigmine (Exelon) on PS2 and APOE genes in Iranian AD patients. Methods: A total of 100 AD patients, 67 patients with sporadic $A D(S A D)$ and 33 patients with familial $A D(F A D)$, receiving rivastigmine therapy and 100 healthy controls were studied. PCR-RFLP was used for genotyping of PS2 and APOE. Results: We found a positive association between the PS2 -A allele and SAD patients $\left(p^{c}=0.01\right)$, and the PS2 $+A /-A$ genotype was significantly more frequent in SAD than FAD patients $\left(p^{c}=0.009\right)$. The APOE4 allele was associated with total AD, SAD and FAD $\left(p^{c}=0.000002\right)$. Patients with the PS2 $+A /-A$ genotype and bigenic genotypes of $+A /-A \cdot \varepsilon 3 / \varepsilon 3$ and $+A /-A \cdot \varepsilon 3 / \varepsilon 4$ were the best responders to Exelon therapy, and those with the PS2 $+\mathrm{A} /+\mathrm{A}$ and APOE $\varepsilon 3 / \varepsilon 4$ genotypes were the worst responders. Conclusion: Our findings suggest that the PS2 and APOE4 alleles and genotypes affect both $A D$ risk and response to rivastigmine therapy.
\end{abstract}

Copyright $\odot 2011$ S. Karger AG, Basel 


\section{Introduction}

Alzheimer disease $(\mathrm{AD})$ is the most common progressive neurodegenerative disorder leading to dementia in the elderly, with increasing prevalence in the near future. The incidence of the disease rises with age, and about $10 \%$ of individuals $>70$ years have significant memory loss and in $>50 \%$ of them AD occurs. It is estimated that about $25-45 \%$ of individuals $>85$ years old have dementia. The prevalence of $\mathrm{AD}$ increases from 2.8 per 1,000 person years in the 65- to 69-year age group to 56.1 per 1,000 person years in those $>90$ years [1]. $\mathrm{AD}$ is the 4th cause of death in modern societies, with progressive impairment in memory and intellectual function resulting in death $[2,3]$.

$\mathrm{AD}$ is a multifactorial and heterogeneous disease [4]. Both genetic and environmental factors are supposed to be involved in disease predisposition. A number of case-control studies have demonstrated associations of some polymorphic genes, such as apolipoprotein E4 (ApoE4), angiotensin-converting enzyme, presenilin 1 (PS1), presenilin 2 (PS2) and amyloid precursor protein (mostly single-nucleotide polymorphisms), with AD [2, 5-10]. In 1993, Corder et al. [7] reported that $40-50 \%$ of the risk for late-onset $\mathrm{AD}$ is attributable to ApoE alleles. An association of a polymorphism in the regulatory region of the PS2 gene with AD was also found $[9,10]$. Mutations in the presenilin gene increase the production of an altered form of $\beta$-amyloid, called A $\beta 42$, as suggested by Scheuner et al. [11] in 1996. Mutations in PS2 cause a less severe AD phenotype, which is due to its lower expression in the brain compared to the PS1 gene [12]. Therefore, polymorphisms affecting the promoter region of PS2 could either increase or decrease the risk for $\mathrm{AD}$. However, the complex nature of $\mathrm{AD}$ with its multifactorial inheritance and more importantly its heterogeneity could lead to the hypothesis that associations with some of these predisposing genes could vary in different $\mathrm{AD}$ populations [7-10, 13].

Since the production of the first cholinesterase inhibitor in 1997, most clinicians consider cholinergic drugs such as rivastigmine (Exelon) in the first-line treatment for mild-tomoderate $\mathrm{AD}$. By blocking the acetyl cholinesterase enzyme, the drug inhibits the breakdown of acetylcholine, an important neurotransmitter associated with memory, resulting in slight improvement in cognition and memory. Recent studies have shown that the abovementioned predisposing genes could mediate the response of patients to drugs [14-16]. Moreover, pioneering pharmacogenetic studies have demonstrated that the therapeutic response in $\mathrm{AD}$ may be genotype specific under different pharmacogenomic conditions $[17,18]$.

Considering the importance of the geographical location, ethnical background of the patients and also the heterogeneity of the disease, in the present study we investigated the influence of Exelon on two Iranian AD patient groups: patients carrying APOE and PS2 susceptibility genes and those not carrying these genes.

\section{Patients and Methods}

\section{Patients and Controls}

In the present study, a total of 100 patients (mean age: $77.7 \pm 7.6$ years, range: $61-96 ; 50$ males: mean age: $77.7 \pm 1$ years, range: $62-87$, and 50 females: mean age: $78.4 \pm 7.5$ years, range: 61-96) with AD diagnosed based on the NINCDS-ADRDA/DSM-IV clinical diagnostic criteria [19], CT and MRI have been studied in the Department of Neurogenetics of the Iranian Center of Neurological Research. Of $100 \mathrm{AD}$ patients, 67 cases (mean age: $77.6 \pm 7.1$ years, range: $61-92$ ) had sporadic $\mathrm{AD}(\mathrm{SAD})$ and 33 cases (mean age: $77.8 \pm 8.5$ years, range: 62-96) familial AD (FAD). All SAD and FAD patients were unrelated and received a standard dose of rivastigmine (Exelon) for 1 year. A neurologist clinically assessed the patients, 
and clinical information, such as gender, age, age at disease onset and family history, was recorded in questionnaire form. To evaluate the severity of $\mathrm{AD}$, mild cognitive impairment and response to rivastigmine, Clinical Dementia Rating scale Sum of Boxes (CDR-SB) scores were assessed accurately at baseline and after 3, 6, 9 and 12 months of treatment.

One hundred healthy volunteers without any signs of dementia who were matched for age/sex and ethnic background were chosen after assessing their cognitive function using the Mini-Mental State Examination [10]. They were selected from the same geographic regions as the patients. All the patients or their legal guardians and control subjects gave their informed consent before being included in the study, which was approved by a local ethics committee.

\section{PS2 and APOE Genotyping}

Blood samples were drawn from each individual, and genomic DNA was extracted from peripheral blood samples using a modified salting-out method [20]. Polymerase chain reaction-restriction fragment length polymorphism (PCR-RFLP) was used for PS2 and APOE genotyping. PS2 polymorphisms were detected by PCR using forward (5'-TAAACTGTGGCATACATGA- $3^{\prime}$ ) and reverse primers (5'-CCATACCCATTGAGAAGGT-3') as described previously [21]. PCR was performed according to the following protocol: $5 \mathrm{~min}$ at $94^{\circ} \mathrm{C}$ followed by 33 cycles for $30 \mathrm{~s}$ at $94^{\circ} \mathrm{C}, 30 \mathrm{~s}$ at $57^{\circ} \mathrm{C}, 60 \mathrm{~s}$ at $72^{\circ} \mathrm{C}$, and $5 \mathrm{~min}$ at $72^{\circ} \mathrm{C}$ as final extension. The PCR products were digested with DdeI restriction endonuclease under optimal condition and were electrophoresed in $8 \%$ polyacrylamide gel. After staining with ethidium bromide, the bands were visualized using a gel documentation system. APOE genotyping was performed using previously described forward (5'-TAAGCTTGGCACGGCTGTCCAAGGA-3') and reverse (5-ACAGAATTCGCCCCGGCCTGGTACAC-3') primers [22] and the following PCR method: preliminary DNA denaturation at $94^{\circ} \mathrm{C}$ for $5 \mathrm{~min}$, followed by 33 cycles of DNA denaturation at $94^{\circ} \mathrm{C}$ for $30 \mathrm{~s}$, annealing at $64^{\circ} \mathrm{C}$ for $30 \mathrm{~s}$ and polymerization at $72^{\circ} \mathrm{C}$ for $60 \mathrm{~s}$. The final extension step was at $72^{\circ} \mathrm{C}$ for $10 \mathrm{~min}$. The PCR products were digested with $H$ haI restriction endonuclease under optimal condition. Then the digested products were electrophoresed on $7 \%$ polyacrylamide gel and were visualized with ethidium bromide.

\section{Statistical Analysis}

All data were entered into a database and analyzed with SPSS, version 16, for Windows. Differences in the frequencies of APOE and PS2 alleles and the genotypes between the patient and control groups were determined using Fisher's exact test or the $\chi^{2}$ test when appropriate. Two-tailed Student's t test was used to compare quantitative data. After Bonferroni's correction for multiple comparisons, corrected $\mathrm{p}\left(\mathrm{p}^{\mathrm{c}}\right)<0.05$ was assumed to be statistically significant.

\section{Results}

\section{Genetic Analysis}

The distribution of PS2 and APOE allele and genotype frequencies in AD patients and healthy controls are shown in table 1. The genotypes of these genes were in Hardy-Weinberg equilibrium for both groups. As shown in table 1, there was no significant association between PS2 alleles and genotypes between the AD and control groups. When AD patients were stratified according to family history (FAD and SAD), a significant positive association between the PS2 -A allele and SAD patients was found $\left(\mathrm{p}^{\mathrm{c}}=0.01\right)$. Comparison of the APOE allele distribution in the $\mathrm{AD}$ and control groups demonstrated a significant difference be- 
Zamani et al.: Pharmacogenetic Study on Rivastigmine in Iranian AD Patients

Table 1. The distribution of PS2 and APOE allele and genotype frequencies in 100 Iranian AD patients and 100 healthy controls

\begin{tabular}{|c|c|c|c|c|c|c|c|c|c|c|}
\hline & \multirow{2}{*}{$\begin{array}{l}\text { All AD } \\
\text { patients } \\
(\mathrm{n}=100)\end{array}$} & \multirow{2}{*}{$\begin{array}{l}\text { Controls } \\
(\mathrm{n}=100)\end{array}$} & \multirow{2}{*}{$\begin{array}{l}\text { SAD } \\
\text { patients } \\
(\mathrm{n}=67)\end{array}$} & \multirow{2}{*}{$\begin{array}{l}\text { FAD } \\
\text { patients } \\
(\mathrm{n}=33)\end{array}$} & \multicolumn{2}{|c|}{ All AD vs. controls } & \multicolumn{2}{|c|}{ SAD vs. controls } & \multicolumn{2}{|c|}{ FAD vs. controls } \\
\hline & & & & & $\mathrm{p}^{\mathrm{c}}$ & OR (95\% CI) & $\overline{p^{c}}$ & OR (95\% CI) & $\mathrm{p}^{\mathrm{c}}$ & OR $(95 \% \mathrm{CI})$ \\
\hline \multicolumn{11}{|l|}{$\begin{array}{l}\text { Alleles } \\
\text { PS? }\end{array}$} \\
\hline$+\mathrm{A}$ & 165 & 179 & 106 & 59 & 0.06 & $0.55(0.32-0.99)$ & 0.01 & $0.44(0.24-0.82)$ & NS & \\
\hline$-\mathrm{A}$ & 35 & 21 & 28 & 7 & 0.06 & $1.81(1.01-3.13)$ & 0.01 & $2.25(1.022-4.09)$ & NS & \\
\hline \multicolumn{11}{|l|}{ APOE } \\
\hline E2 & 6 & 13 & 4 & 2 & NS & & NS & & NS & \\
\hline E3 & 152 & 177 & 102 & 50 & 0.001 & $0.42(0.24-0.71)$ & 0.003 & $0.41(0.23-0.75)$ & 0.01 & $0.41(0.20-0.81)$ \\
\hline E4 & 42 & 10 & 28 & 14 & $2 \times 10^{-6}$ & $4.86(2.43-9.75)$ & 0.00001 & $5.02(2.33-10.11)$ & 0.0002 & $5.12(2.17-11.55)$ \\
\hline \multicolumn{11}{|l|}{$\begin{array}{l}\text { Genotypes } \\
\text { PS2 }\end{array}$} \\
\hline$+\mathrm{A} /+\mathrm{A}$ & 69 & 79 & 41 & 28 & NS & & 0.01 & $0.42(0.22-0.83)$ & NS & \\
\hline$+\mathrm{A} /-\mathrm{A}$ & 27 & 21 & 24 & 3 & NS & & 0.049 & $2.10(1.05-4.11)$ & NS & \\
\hline$-\mathrm{A} /-\mathrm{A}$ & 4 & 0 & 2 & 2 & NS & & NS & & NS & \\
\hline \multicolumn{11}{|l|}{ APOE } \\
\hline$\varepsilon 3 \varepsilon 3$ & 58 & 77 & 39 & 19 & 0.006 & $0.42(0.23-0.76)$ & 0.01 & $0.042(0.22-0.81)$ & 0.04 & $0.41(0.18-0.92)$ \\
\hline$\varepsilon 3 \varepsilon 4$ & 33 & 10 & 22 & 11 & 0.001 & $4.28(2.02-9.05)$ & 0.0004 & $4.40(1.91-9.50)$ & 0.004 & $4.50(1.73-11.25)$ \\
\hline$\varepsilon 4 \varepsilon 4$ & 3 & 0 & 2 & 1 & NS & & NS & & NS & \\
\hline$\varepsilon 2 \varepsilon 4$ & 3 & 0 & 2 & 1 & NS & & NS & & NS & \\
\hline$\varepsilon 2 \varepsilon 3$ & 3 & 13 & 2 & 1 & 0.02 & $0.23(0.07-0.73)$ & 0.02 & $0.21(0.07-0.90)$ & NS & \\
\hline
\end{tabular}

Fisher's exact test with correction (2 tailed). All significant $\mathrm{p}^{\mathrm{c}}$ are shown in bold.

tween the two groups. The APOE4 allele was positively associated and the APOE3 allele was negatively associated with total $\mathrm{AD}, \mathrm{SAD}$ and FAD (table 1). The results also indicated that in contrast to the APOE $\varepsilon 3 / \varepsilon 3$ genotype, which was significantly more frequent in controls, the APO $\varepsilon 3 / \varepsilon 4$ genotypes were significantly more frequent in total AD, SAD and FAD patients than in controls, and these differences were statistically significant (table 1).

Comparisons of PS2 and APOE allele and genotype frequencies in SAD and FAD patients are shown in table 2. Sixty-seven percent of the patients had SAD and 33\% had FAD. The results also showed that the $+\mathrm{A} /-\mathrm{A}$ genotype of PS2 was significantly more frequent in SAD than FAD $\left(\mathrm{p}^{\mathrm{c}}=0.009\right)$. There were no statistically significant differences in PS2 and APOE allele or genotype frequencies between SAD and FAD patients.

\section{Response to Rivastigmine}

Monogenic-Related Drug Response. PS2- and APOE-associated responses to Exelon therapy in $\mathrm{AD}$ patients are shown in figures 1 and 2. Analysis of drug response according to various genotypes showed that $\mathrm{AD}$ patients with the $\mathrm{PS} 2+\mathrm{A} /-\mathrm{A}$ genotype were the best responders among all $\mathrm{AD}$ patients. In this group of $\mathrm{AD}$ patients, disease progression is not significantly different compared to baseline. In contrast, patients with the PS2 +A/+A and $\mathrm{APO} \varepsilon 3 / \varepsilon 4$ genotypes were the worst responders, with severity of disease being significantly increased after treatment with Exelon compared to baseline. Other genotype frequencies were low and their therapeutic response was not identified.

Drug Response according to Gender and Monogenic Genotype. PS2- and APOE-associated responses to Exelon therapy in male and female $\mathrm{AD}$ patients are shown in figures 3 and 4 , respectively. When drug response is analyzed in relation to gender and different monogenic genotypes of these two genes, both male and female AD patients with the PS2 +A/-A genotype were the best responders. In other genotype carriers, slight progression of disease was noted compared to baseline. 
Table 2. The distribution of PS2 and APOE allele and genotype frequencies in Iranian SAD and FAD patients

\begin{tabular}{cccll}
\hline & $\begin{array}{l}\text { SAD patients } \\
(\mathrm{n}=67)\end{array}$ & $\begin{array}{l}\text { FAD patients } \\
(\mathrm{n}=33)\end{array}$ & \multicolumn{2}{l}{ SAD vs. FAD } \\
\cline { 5 - 5 } & & & $\mathrm{p}^{\mathrm{c}}$ & $\mathrm{OR}(95 \% \mathrm{CI})$ \\
\hline Alleles & & & & \\
PS2 & & & & \\
+A & 106 & 59 & 0.078 & $0.45(0.20-1.10)$ \\
-A & 28 & 7 & 0.078 & $2.23(0.91-4.94)$ \\
APOE & & & & \\
E2 & 4 & 2 & NS & \\
E3 & 102 & 50 & NS & \\
E4 & 28 & 14 & NS & \\
\hline Genotypes & & & & \\
PS2 & & & & \\
$+\mathrm{A} /+\mathrm{A}$ & 41 & 28 & 0.030 & $0.28(0.11-0.82)$ \\
$+\mathrm{A} /-\mathrm{A}$ & 24 & 3 & $\mathbf{0 . 0 0 9}$ & $5.58(1.55-15.52)$ \\
$-\mathrm{A} /-\mathrm{A}$ & 2 & 2 & NS & \\
APOE & & & & \\
$\varepsilon 3 \varepsilon 3$ & 39 & 19 & NS & \\
$\varepsilon 3 \varepsilon 4$ & 22 & 11 & NS & \\
$\varepsilon 4 \varepsilon 4$ & 2 & 1 & NS & \\
$\varepsilon 2 \varepsilon 4$ & 2 & 1 & NS & \\
$\varepsilon 2 \varepsilon 3$ & 2 & 1 & NS & \\
\hline
\end{tabular}

Bigenic Genotype-Related Drug Response. Bigenic genotype-related responses to Exelon therapy in $\mathrm{AD}$ patients are shown in figure 5. Our findings indicated that bigenic genotypes $+\mathrm{A} /-\mathrm{A} \cdot \varepsilon 3 / \varepsilon 3$ and $+\mathrm{A} /-\mathrm{A} \cdot \varepsilon 3 / \varepsilon 4$ carriers were the best responders to Exelon therapy.

\section{Discussion}

$\mathrm{AD}$ is a complex and genetically heterogeneous disorder. Twin and family studies have indicated that certain genes contribute to the development of AD. Among those, mutations in PS2 on chromosome 1 and APOE on chromosome 19 have been shown to play an important role in the pathogenicity of $\mathrm{AD}[9,11,23]$. Based on the complex nature of $\mathrm{AD}$ with its numerous possible associated gene mutations and more importantly the heterogeneity of the disease, it is highly probable that some of these $\mathrm{AD}$-predisposing genes could vary among different AD populations [7-10,13]. Moreover, it seems that not all AD patients will respond to a given therapy due to disease heterogeneity at molecular level. This assumption is supported by the study by Schneider and Farlow [24] in 1995, which indicated that only up to $50 \%$ of AD patients had a significant response to acetylcholine esterase inhibitors.

In this study, we investigated both the contribution of APOE and PS2 alleles and genotypes regarding the risk of $\mathrm{AD}$ and, for the first time, the influence of Exelon (an acetylcholine esterase inhibitor) on two Iranian AD patient groups: patients with or without the susceptibility genes APOE and PS2.

We found no significant association between PS2 alleles or genotypes and total AD patients compared to controls. However, after stratifying AD patients according to family history (FAD and SAD), a significant positive association was found between the PS2 -A allele and SAD patients $\left(\mathrm{p}^{\mathrm{c}}=0.01\right)$. In 2002, for the first time, Riazanskaia et al. [21] detected a 
Fig. 1. PS2 genotype-related therapeutic response to Exelon therapy in 100 Iranian AD patients. a coef. $=y$-intercept of the line; b coef. $=$ slope or gradient of the line.

Fig. 2. APOE genotype-related therapeutic response to Exelon therapy in 100 Iranian AD patients. a coef. $=y$-intercept of the line; $b$ coef. $=$ slope or gradient of the line.

Fig. 3. PS2 and APOE genotyperelated therapeutic response to Exelon therapy in male AD patients. a coef. $=y$-intercept of the line; $b$ coef. $=$ slope or gradient of the line.

\begin{tabular}{l|l}
\hline Dement Geriatr Cogn Disord Extra 2011;1:180-189 \\
\hline \begin{tabular}{l|l} 
DOI: 10.1159/000329514 & $\begin{array}{l}\text { @ 2011 S. Karger AG, Basel } \\
\text { www.karger.com/dee }\end{array}$ \\
Published online: June 29, 2011 &
\end{tabular}
\end{tabular}

Zamani et al.: Pharmacogenetic Study on Rivastigmine in Iranian AD Patients
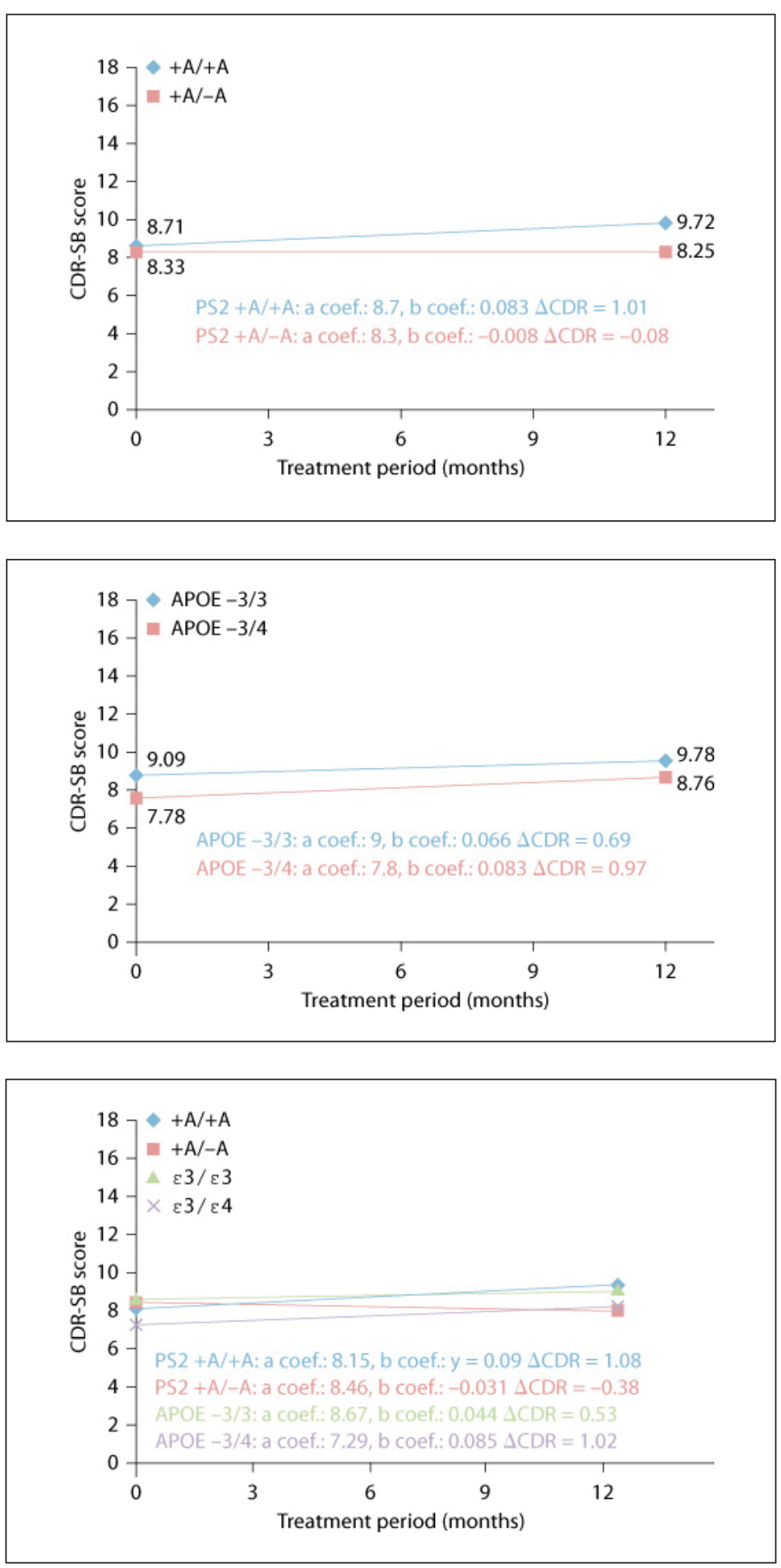

polymorphism in the $5^{\prime}$-upstream promoter region of the PS2 gene caused by a single adenosine nucleotide deletion located between $-1,500$ and $-1,600$ bp upstream from the transcription start site. The wild type of the polymorphic sequence $(\mathrm{PS} 2+\mathrm{A})$ is similar to the interferon regulatory factor (IRF-2). It acts as repressor of transcription. The deletion polymorphism (PS2 -A) created a new potential regulatory site for the transcription factor C/EBF 
Fig. 4. PS2 and APOE genotyperelated therapeutic response to Exelon therapy in female AD patients. a coef. $=y$-intercept of the line; $b$ coef. $=$ slope or gradient of the line.

Fig. 5. Combined APOE and PS2 genotype-related therapeutic response to Exelon therapy in $\mathrm{AD}$ patients. a coef. $=$ y-intercept of the line; b coef. = slope or gradient of the line.
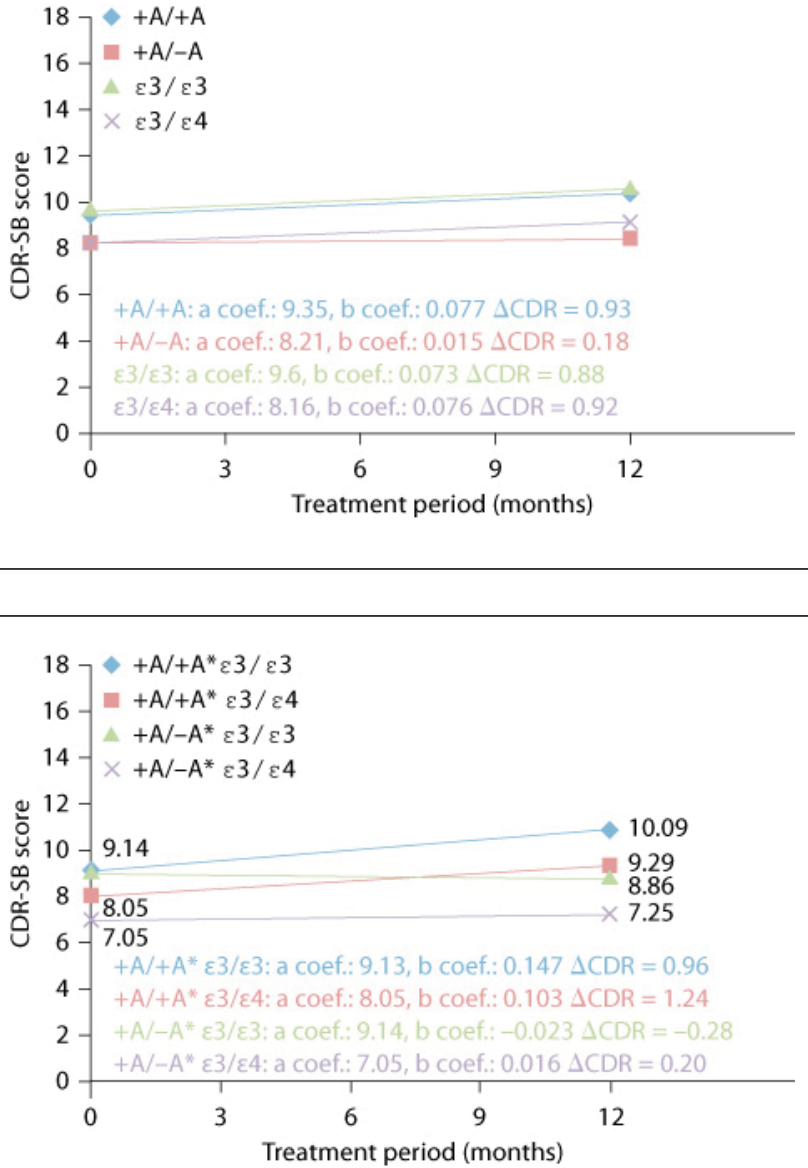

(CCAAT/enhancer) which leads to the promotion of transcription and finally the rise in peptide fragments of amyloid precursor proteins [21]. In agreement with the studies of Riazanskaia et al. [21] in 2002 and Liu and Jia [10] in 2008, our findings showed an association of the $-\mathrm{A}$ allele with the risk of AD but were in contrast to studies performed in Italian, Japanese and Polish populations $[9,13,25]$. This could be due to the genetic heterogeneity of AD, ethnic and regional differences and also sample size. Our results also showed that the PS2 $+\mathrm{A} /-\mathrm{A}$ genotype is significantly more frequent in SAD than FAD $\left(\mathrm{p}^{\mathrm{c}}=0.009\right)$. Collectively, these findings suggested that the $-\mathrm{A}$ allele and the $+\mathrm{A} /-\mathrm{A}$ genotype of PS2 may affect the SAD risk in Iranians.

In agreement with several studies performed in different ethnic groups [26-28], our findings demonstrated that the APOE 4 allele and $\varepsilon 3 / \varepsilon 4$ genotypes were positively and the APOE3 allele negatively associated with total AD, SAD and FAD (table 1). Our results were not in agreement with a few studies performed on Nigerian and East-African populations, in which the results did not show any correlations $[29,30]$. Nevertheless, our findings indicated that the APOE4 allele is a genetic risk factor for both SAD and FAD in the Iranian population. However, the underlying mechanism(s) showing how APOE4 affects AD risk and progression remain to be elucidated. However, evidence accumulates that the differential effects of APOE4 on amyloid $\beta$ aggregation and clearance play the main role in AD pathogenesis. Other potential mechanisms, such as cholesterol/phospholipid homeostasis 
and synaptic integrity, the modulation of neurotoxicity and tau phosphorylation, as well as its role in neuronal survival may also be effective in AD pathogenesis [15].

Numerous pharmacogenetic studies have demonstrated that the therapeutic response in AD seems to be genotype specific under different pharmacogenomic conditions and it is also influenced by gender $[17,18]$. We investigated these hypotheses in Iranian AD patients, and our results indicated that patients with the PS2 $+\mathrm{A} /-\mathrm{A}$ genotype were the best responders and patients with the $\mathrm{PS} 2+\mathrm{A} /+\mathrm{A}$ and APOE $\varepsilon 3 / \varepsilon 4$ genotypes were the worst responders. The exact mechanisms through which the PS2 genotype status affects response to certain acetylcholine esterase inhibitors are still unknown but in terms of the APOE genotype, this may not be surprising because the APOE4 gene has been found to influence choline acetyltransferase activity in the cortex and hippocampus [31,32], and the number of copies of APOE alleles was inversely related with residual choline acetyltransferase activity in the brain [15]. Our results revealed that both male and female AD patients with PS2 $+\mathrm{A} /-\mathrm{A}$ were the best responders. In contrast with the results of Farlow et al. [33] in 1996, our study did not reveal any significant effect of ApoE on response to therapy in males or females. Regarding the bigenic genotype-related therapeutic response to Exelon therapy, the results indicated that $+\mathrm{A} /-\mathrm{A} \cdot \varepsilon 3 / \varepsilon 3$ and $+\mathrm{A} /-\mathrm{A} \cdot \varepsilon 3 / \varepsilon 4$ genotype carriers were the best responders. These findings might demonstrate that gene-gene interactions and also different polymorphic variants involved in $\mathrm{AD}$ pathogenesis may affect the therapeutic response of $\mathrm{AD}$ patients.

In conclusion, our findings suggested that the PS2 - A allele and the $+\mathrm{A} /-\mathrm{A}$ genotype contribute to the SAD risk. The results also demonstrated that the APOE4 allele is a genetic risk factor for both SAD and FAD in Iranian AD patients. Moreover, patients with the PS2 $+\mathrm{A} /-\mathrm{A}$ genotype and bigenic genotype carriers of $+\mathrm{A} /-\mathrm{A} \cdot \varepsilon 3 / \varepsilon 3$ and $+\mathrm{A} /-\mathrm{A} \cdot \varepsilon 3 / \varepsilon 4$ were the best responders to Exelon therapy.

\section{Acknowledgments}

We gratefully acknowledge the AD patients and their families who participated in this study. This study was supported by a research grant from the Tehran University of Medical Sciences.

\section{References}

-1 Kukull WA, Higdon R, Bowen JD, McCormick WC, Teri L, Schellenberg GD, van Belle G, Jolley L, Larson EB: Dementia and Alzheimer disease incidence: a prospective cohort study. Arch Neurol 2002;59:1737-1746.

-2 Theuns J, Del-Favero J, Dermaut B, van Duijn CM, Backhovens H, Van den Broeck MV, Serneels S, Corsmit E, Van Broeckhoven CV, Cruts M: Genetic variability in the regulatory region of presenilin 1 associated with risk for Alzheimer's disease and variable expression. Hum Mol Genet 2000;9:325331.

-3 Theuns J, Van Broeckhoven C: Transcriptional regulation of Alzheimer's disease genes: implications for susceptibility. Hum Mol Genet 2000;9:2383-2394.

-4 Iqbal K, Grundke-Iqbal I: Alzheimer disease is multifactorial and heterogeneous. Neurobiol Aging 2000;21:901-902.

-5 Kehoe PG, Russ C, McIlory S, Williams H, Holmans P, Holmes C, Liolitsa D, Vahidassr D, Powell J, McGleenon B, Liddell M, Plomin R, Dynan K, Williams N, Neal J, Cairns NJ, Wilcock G, Passmore P, Lovestone S, Williams J, Owen MJ: Variation in DCP1, encoding ACE, is associated with susceptibility to Alzheimer disease. Nat Genet 1999;21:71-72. 
-6 Heijmans BT, Slagboom PE, Gussekloo J, Droog S, Lagaay AM, Kluft C, Knook DL, Westendorp RG: Association of APOE $\varepsilon 2 / \varepsilon 3 / \varepsilon 4$ and promoter gene variants with dementia but not cardiovascular mortality in old age. Am J Med Genet 2002;107:201-208.

-7 Corder E, Saunders A, Strittmatter W, et al: Gene dose of apolipoprotein E type 4 allele and the risk of Alzheimer's disease in late onset families. Science 1993;261:921-923.

$\checkmark 8$ Corder E, Saunders A, Risch N, et al: Protective effect of apolipoprotein E type 2 allele for late onset Alzheimer disease. Nat Genet 1994;7:180-183.

-9 Quan W, Yasuda M, Hashimoto M, Yamamoto Y, Ishii K, Kazui H, Mori E, Kakigi T, Maeda K: Polymorphism of the regulatory region of the presenilin-2 gene in sporadic Alzheimer's disease: a casecontrol study. J Neurol Sci 2006;240:71-75.

$\checkmark 10$ Liu Z, Jia J: The association of the regulatory region of the presenilin-2 gene with Alzheimer's disease in the Northern Han Chinese population. J Neurol Sci 2008;264:38-42.

-11 Scheuner D, Eckman C, Jensen M, Song X, Citron M, Suzuki N, Bird TD, Hardy J, Hutton M, Kukull W, Larson E, Levy-Lahad E, Viitanen M, Peskind E, Poorkaj P, Schellenberg G, Tanzi R, Wasco W, Lannfelt L, Selkoe D, Younkin S: Secreted amyloid beta-protein similar to that in the senile plaques of Alzheimer's disease is increased in vivo by the presenilin 1 and 2 and APP mutations linked to familial Alzheimer's disease. Nat Med 1996;2:864-870.

-12 Sherrington R, Rogaev EI, Liang Y, Rogaeva EA, Levesque G, Ikeda M, Chi H, Lin C, Li G, Holman $\mathrm{K}$, et al: Cloning of a gene bearing missense mutations in early-onset familial Alzheimer's disease. Nature 1995;375:754-760.

13 Di Natale M, Perri M, Kawarai T, Maletta R, Tomaino C, Sato C, et al: Absence of association between Alzheimer disease and the regulatory region polymorphism of the PS2 gene in an Italian population. Neurosci Lett 2003;343:210-212.

-14 Gavrilova SI, Kolykhalov IV, Korovaĭtseva GI, Zharikov GA, Kalyn IaB, Selezneva ND: ApoE genotype and efficacy of neurotrophic and cholinergic therapy in Alzheimer's disease (in Russian). Zh Nevrol Psikhiatr Im S S Korsakova 2005;105:27-34.

$\checkmark 15$ Poirier J: Apolipoprotein E represents a potent gene-based therapeutic target for the treatment of sporadic Alzheimer's disease. Alzheimers Dement 2008;4:S91-S97.

$\checkmark 16$ Schork NJ, Topol EJ: Genotype-based risk and pharmacogenetic sampling in clinical trials. J Biopharm Stat 2010;20:315-333.

17 Cacabelos R: Pharmacogenomics in Alzheimer's disease. Drug News Perspect 2000;13:252-254.

- 18 Cacabelos R, Alvarez A, Lombardi V, Fernández-Novoa L, Corzo L, Pérez P, Laredo M, Pichel V, Hernández A, Varela M, Figueroa J, Prous J Jr, Windisch M, Vigo C: Pharmacological treatment of Alzheimer disease: from psychotropic drugs and cholinesterase inhibitors to pharmacogenomics. Drugs Today (Barc) 2000;36:415-499.

- 19 McKhann G, Drachman D, Folstein M, Katzman R, Price D, Stadlan EM: Clinical diagnosis of Alzheimer's disease: report of the NINCDS-ADRDA Work Group under the auspices of Department of Health and Human Services Task Force on Alzheimer's Disease. Neurology 1984;34:939-944.

-20 Miller SA, Dykes DD, Polesky HF: A simple salting out procedure for extracting DNA from human nucleated cells. Nucleic Acids Res 1988;16:1215-1218.

-21 Riazanskaia N, Lukiw WJ, Grigorenko A, Korovaitseva G, Dvoryanchikov G, Moliaka Y, Nicolaou M, Farrer L, Bazan NG, Rogaev E: Regulatory region variability in the human presenilin-2 (PSEN2) gene: potential contribution to the gene activity and risk for AD. Mol Psychiatry 2002;7:891-898.

-22 Emi M, Wu LL, Robertson MA, Myers RL, Hegele RA, Williams RR, White R, Lalouel JM: Genotyping and sequence analysis of apolipoprotein E isoforms. Genomics 1988;3:373-379.

23 Salloway S, Gur T, Berzin T, Tavares R, Zipser B, Correia S, Hovanesian V, Fallon J, Kuo-Leblanc V, Glass D, Hulette C, Rosenberg C, Vitek M, Stopa E: Effect of APOE genotype on microvascular basement membrane in Alzheimer's disease. J Neurol Sci 2002;203-204:183-187.

24 Schneider LS, Farlow MR: Predicting response to cholinesterase inhibitors in Alzheimer's disease. Possible approaches. CNS Drugs 1995;4:114-124.

-25 Gacia M, Safranow K, Gabryelewicz T, Styczyńska M, Pepłońska B, Dziedziejko V, Jakubowska K, Chlubek D, Zekanowski C, Barcikowska M: Two polymorphisms of presenilin-2 gene (PSEN2) 5' regulatory region are not associated with Alzheimer's disease (AD) in the Polish population. J Neural Transm 2008;115:85-90.

-26 Poirier J, Davignon J, Bouthillier D, Kogan S, Bertrand P, Gauthier S: Apolipoprotein E polymorphism and Alzheimer's disease. Lancet 1993;342:697-699. 
-27 Martins RN, Clarnette R, Fisher C, Broe GA, Brooks WS, Montgomery P, Gandy SE: ApoE genotypes in Australia: roles in early and late onset Alzheimer's disease and Down's syndrome. Neuroreport 1995;6:1513-1516.

-28 Saunders AM, Strittmatter WJ, Schmechel D, George-Hyslop PH, Pericak-Vance MA, Joo SH, Rosi BL, Gusella JF, Crapper-MacLachlan DR, Alberts MJ, et al: Association of apolipoprotein E allele epsilon 4 with late-onset familial and sporadic Alzheimer's disease. Neurology 1993;43:1467-1472.

-29 Osuntokun BO, Sahota A, Ogunniyi AO, Gureje O, Baiyewu O, Adeyinka A, Oluwole SO, Komolafe O, Hall KS, Unverzagt FW, et al: Lack of an association between apolipoprotein E epsilon 4 and Alzheimer's disease in elderly Nigerians. Ann Neurol 1995;38:463-465.

-30 Sayi JG, Patel NB, Premkumar DR, Adem A, Winblad B, Matuja WB, Mtui EP, Gatere S, Friedland RP, Koss E, Kalaria RN: Apolipoprotein E polymorphism in elderly East Africans. East Afr Med J 1997;74:668-670.

- 31 Combarros O, Alvarez-Arcaya A, Sánchez-Guerra M, Infante J, Berciano J: Candidate gene association studies in sporadic Alzheimer's disease. Dement Geriatr Cogn Disord 2002;14:41-54.

-32 Soininen H, Kosunen O, Helisalmi S, Mannermaa A, Paljärvi L, Talasniemi S, Ryynänen M, Riekkinen P Sr: A severe loss of choline acetyltransferase in the frontal cortex of Alzheimer patients carrying apolipoprotein epsilon 4 allele. Neurosci Lett 1995;187:79-82.

-33 Farlow MR, Lahiri DK, Poirier J, Davignon J, Hui S: Apolipoprotein E genotype and gender influence response to tacrine therapy. Ann NY Acad Sci 1996;802:101-110. 